\title{
Cratippus or Theopompus?
}

\author{
By E. M. Walker.
}

Any one who essays the task of determining the authorship of the papyrus discovered by Dr. Grenfell and Dr. Hunt, and published by them in Part $\mathrm{V}$ of the OXYRHYNCHUS PAPYRI, finds himself confronted with an initial difficulty. The problem of the identity of the New Historian has been discussed so fully, so ably, and so impartially, by the editors, that it is inevitable that in attempting to give a definite answer to the question which they have left indeterminate, one should go over ground which they have already traversed. It is not likely that much new evidence will be forthcoming. If the question can be decided at all, it will be decided by the process of weighing the evidence already presented. Much of that evidence requires no restatement. Many of the conclusions at which the editors arrive will not be seriously questioned. Consequently, it will often be unnecessary to do more than state in summary form arguments which can be unreservedly accepted.

Upon grounds of internal evidence it may certainly be concluded that the author wrote between the Peace of Antalcidas and Alexander's conquest of Persia. In XI, 38, the constitution of the Boeotian League, as it was in B.C. 395,

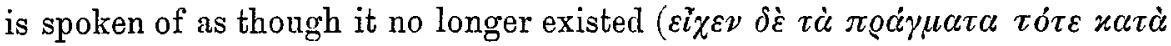

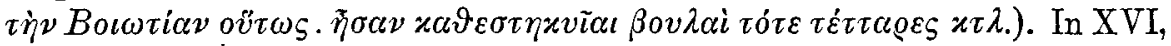

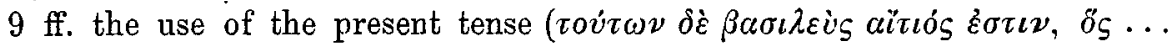

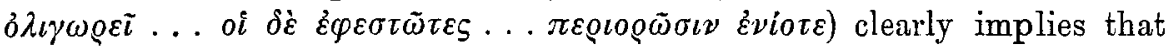
the Persian Empire was still standing. The period of composition is thus determined by the year 387 , at one end, and the year 334 , at the other. The period included in the author's complete work can also be determined with tolerable certainty, at any rate at one end. The $\ddot{\varepsilon} \tau o \varsigma$ ö $\gamma \delta$ ooov in III, 10 indicates that the year 403-2 (or possibly, 402-1) was the starting point either of the whole work, or of a fresh section of the work. I am disposed to agree with the editors' conclusion that the year in question is not the starting point of the whole work. The passage in II, 27, to which they appeal, in which an incident of the year 411 is said to have been

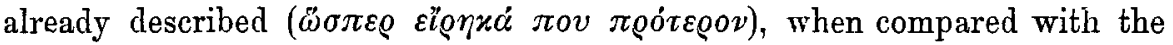
references to certain events of the Peloponnesian War in regard to which no similar statement is made, goes far to prove that the writer began, where Thucydides left off, in 411 . There is nothing to indicate the point at which the narrative ended. It may have been the battle of Cnidus, or the Peace of Antalcidas. It is improbable that the period covered by a work composed on so large a scale would have extended to much more than twenty years. The two conditions, therefore, which must be satis- 
fied by any hypothesis as to the identity of the writer are, firstly, that the work was composed between 387 and 334 , and secondly, that the period which it covered began at 411 , and ended, in all probahility, at 394 or 387 . From the list of possible claimants to the honours of authorship the Atthidographs may be excluded. In an Atthis we should hardly expect to find a minute account of the campaigns of Agesilaus $\left.{ }^{1}\right)$. Of the remaining writers who satisfy the first condition, there are only three that need be seriously considered - Ephorus, Theopompus, and Cratippus. There is, to be sure, Herodicus. We have it on the authority of the

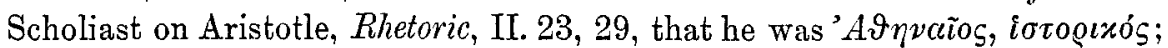
and, as a contemporary of Thrasymachus and Polus, he may, perhaps, pass in point of date. But to take refuge in Herodicus would be a step only one degree removed from the pure agnosticism deprecated by the editors.

The one argument in favour of identifying the writer with Ephorus is the close correspondence which can be traced between the narrative of Diodorus and certain passages in the papyrus. Unless the received view as to the relation of Diodorus to Ephorus is to be completely abandoned, it is certain that, in view of this correspondence, we must choose between two alternatives. Either Ephorus is the New Historian, or he used him. The arguments against the former of these alternatives are conclusive. In the first place, Ephorus does not satisfy the second of the conditions laid down. His History was a universal history, not the history of a particular period. In the second place, the scale of the work is quite inconsistent with the idea of a universal history. The extant columns of the papyrus which deal with the events of the year 395 are equal in amount to more than half a book of Xenophon's Hellenica. If allowance is made for the missing columns, the amount would certainly not be less than three-quarters of a book. Ephorus covered the interval between 399 and 386, a period of 13 years, in three books; for in book 18 the sending of Dercylidas to Asia (399) is recorded, while in book 20 the $\delta$ เotxiouós of Mantinea (386) found a place (Eph. Frag. 130, 138). It must be remembered, too, in comparing the scale of the two works, that Ephorus included Sicilian history, to which no allusion occurs in the papyrus. It is certain, then, that Ephorus is not the author of whom we are in search.

The arguments in favour of Theopompus may be summarized as follows. There is, to begin with, the coincidence of period and the agreement of scale. Theopompus began where Thucydides left off, and he stopped at the battle of Cnidus. To these 17 years he devoted 12 books;

1) G. de Sanctis, l'Attide di Androzione e un papiro di Oxyrhynchos (Atti della R. Accademia delle Scienze di Torino, Vol. XLIII, Torino, 1908) identifies the author of the fragment with the atthidograph Androtion. The arguments in favour of this identification appear to me slight; the objections to it, on the ground of subject, date, and scale, much more considerable than the writer realises. 
an average, roughly speaking, of a book to a year and a half (cf. Diod. 13, 42 and 14, 84). Secondly, the fragments of his Philippica indicate that he was excessively fond of digressions; such digressions are a marked feature in the narrative of the papyrus. In the third place, Theopompus is praised by Dionysius of Halicarnassus for his insight into causes and motives, and censured by Polybius for the conventional character of his battles. Insight into causes and motives is claimed for our author, while it is suggested that the ambuscades described in V, 57 and XIX, 22 have a suspiciously conventional air. Fourthly, there are two verbal coinci-

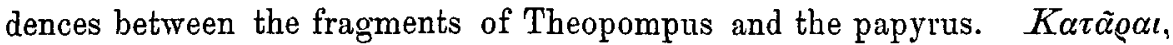
in the sense of $\varepsilon \lambda v \varepsilon i \nu$, which is quoted from Theopompus by a grammarian (Frag. 327), occurs twice over in the papyrus (XVIII, 39 and VIII, 22); and the form Ka@л $\alpha \sigma \varepsilon v^{\prime}$, meaning a man of Carpasus in Cyprus, which is quoted by Stephanus of Byzantium as occurring in Theopompus, $\varepsilon \nu \delta \varepsilon x \alpha \dot{\alpha} \tau$, is found in XVI, 37 and XVII, 16. It is further claimed that the judgments passed by our author upon statesmen and political parties are consistent with the political attitude which may be legitimately attributed to Theopompus. And finally, it is argued that there is much in the style of Theopompus, so far as it can be inferred from the extant fragments, which is in harmony with the style of the papyrus, especially as regards the use of particular words or constructions.

It is evident that these arguments are of very different value. On the question of style something will be said later on. The utmost that can be urged, in this respect, in favour of the identification of the author with Theopompus is that upon grounds of style, if the style is to be judged solely from the extant fragments, as much may be said for the hypothesis as against it. To some of the other arguments little weight can be attached. Take the argument about the writer's political views. E. Meyer thinks that Theopompus' aristocratical leanings, combined with the sincere desire for truth with which he credits him, would lead him to adopt the moderately conservative attitude which is characteristic of our historian. There is, indeed, nothing hypothetical about the aristocratical leanings of Theopompus, but there is much that is hypothetical in his sincere desire for the truth. We might with equal justice attribute to him strong prejudices strongly expressed. But in any case, even if this political attitude could be established, it would not be peculiar to him. If we want to discorer a close parallel to the judgments of the New Historian on men and measures, we shall find it, not in the fragments of Theopompus, but in the Athenaion Politeia of Aristotle (e. g. A. P. 34, 3 and 40,1 and 2, compared with 1, $14 \mathrm{ff}$ ). His general attitude appears to be much the same as that of Isocrates, or even of Thueydides himself. The motive attributed to the leaders of the extreme wing of the democratical party at Athens $\left(11,10 \mathrm{ff} . \dot{\varepsilon} \pi l_{-}\right.$

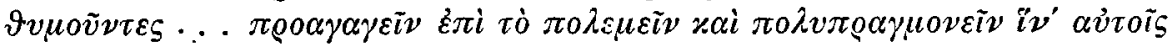




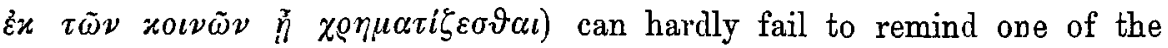
explanation which Thucydides gives of the policy of Cleon $(\delta \delta \dot{\varepsilon} \gamma \varepsilon v o \mu \varepsilon \dot{\nu} \eta \bar{s}$

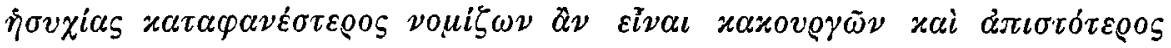

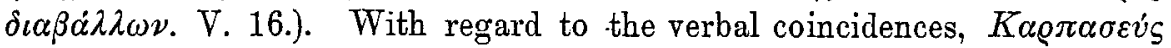
would be striking if $\varepsilon^{2} \nu \delta \varepsilon x \alpha \dot{\tau} \omega$ refers to the Hellenica, and if it were certain that the period of the naval war to which the mutiny at Caunus belongs fell within Theopompus' tenth book. The latter point is fairly certain, though $\dot{\varepsilon} \nu \delta \varepsilon x \dot{\alpha} \tau \omega$, if analogy is to be followed, should mean in the tenth book of the Philippica. The strong argument is the first one; and it is very strong. I am prepared to admit that it would go far to make good the claim of Theopompus, if there were no stronger arguments on the other side. Prima facie it is certainly improbable that there should have been two works, composed on the same scale, covering the same ground, and written at the same period. It is also improbable that a work of such magnitude should have survived to so late a date as that at which the papyrus was transcribed, unless it were from the pen of a writer known to fame. The second argument, on the other hand, is not so strong as it looks. We have both external testimony, and the internal evidence of the fragments, for the frequency of digressions in the Philippica. We have neither external testimony, nor internal evidence, in the case of the Hellenica. If it is argued that the fragments of the latter are too few and too short to enable us to form a judgement, it may be replied that what is true of a work, in which 58 books were allotted to 24 years, need not be true of one, in which 12 books covered 17 years. Few writers can have been as discursive as Theopompus in the Philippica. Digressions such as those met with in the papyrus could probably be paralleled in a good many historians.

Such then being the arguments in favour of the identification of the papyrus with the Hellenica of Theopompus, what are the objections that may be urged against this hypothesis? Against the less convincing arguments in favour of it there may be set the minor objections. The third argument, e. g., (insight into causes and motives) is a good deal more than outweighed by the objection based on the treatment of Agesilaus. It is clear that Agesilaus was

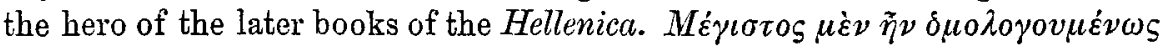

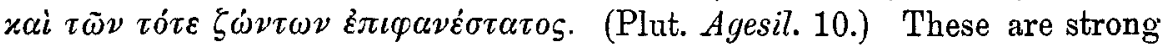
words; but of the hero-worship which is implied in them there is not a trace to be discovered in the papyrus. On the contrary, as the editors point out, the tendency of the writer is to exalt the achievements of Conon at the expense of those of Agesilaus. The more serious objections may be reduced to three, based respectively upon chronology, relationship, and style. Any one of the three, I venture to submit, is of itself sufficient to determine the verdict. I cannot but regard their cumulative force as irresistible.

The chronological argument turns upon the date of Theopompus, on the one hand, and the date of the composition of the history, on the 
other, of which we have a fragment in the papyrus. As to Theopompus, our evidence is at once precise and credible. The witness is Photius, who had read the Philippica, 53 books of which were still extant in his day. He asserts that, when Theopompus was restored to his native Chios by the rescript of Alexander, he was 45 years of age. This would fix his birth to 378 , the rescript being not earlier than 333 . He further tells us that after Alexander's death he took refuge in Egypt with $\mathrm{K}$ ing Pto-

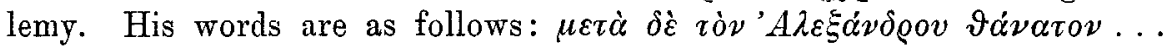

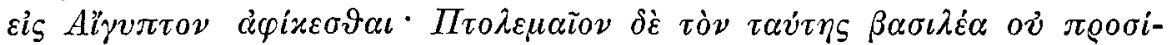

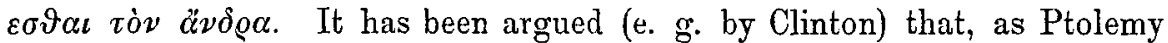
did not assume the royal title until 306 , Theopompus must have been alive at this date. It is possible, however, that Photius has used the term $\beta \alpha \sigma i \lambda \varepsilon^{\alpha} \alpha$ inaccurately; if so, the flight to Egypt could be dated back to 323 , or thereabouts. In either case, the two statements of Photius are in harmony with each other. They are also entirely consistent with any reasonable date for the composition of the Philippica. Theopompus cannot have conceived the idea of writing a history of Philip's reign until he had grasped the significance of his career. It is difficult to believe that he should have planned a work on so vast a scale until he had grasped the full significance of that career. Chaeronea is the earliest probable moment, the Peace of Philocrates the earliest possible one. A work in 58 books must have occupied many years of his liternry activity. If it was begun soon after 338 , it cannot well have been finished before $320^{1}$ ). A date 10 years later would be still more probable. What Suidas tells us,

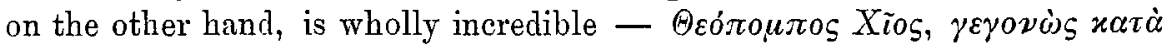

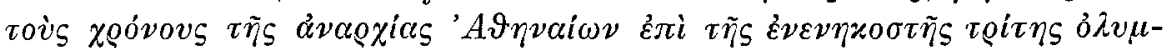

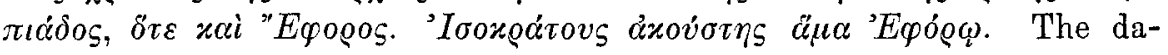
ting by the àvaQxia excludes the possibility of a corruption in the number of the Olympiad; while the meaning to be assigned to $\gamma \varepsilon \gamma o \nu \omega s$ is deter-

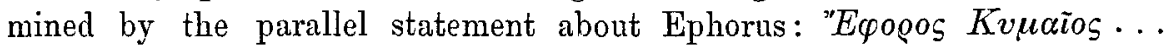

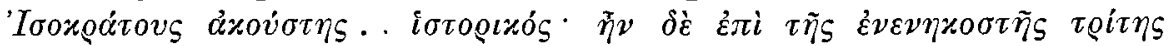

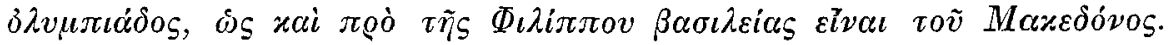
${ }^{3} H \nu$ is, clearly, vixit, flortit; ; and $\gamma \varepsilon \gamma o v \omega ́ s$, equally clearly, is not natus. To harmonise a floruit in 404 with a literary activity extending to 320 is beyond the resources of ingenuity however great. For our present purpose, all that ean be done with Suidas is to dismiss him from consideration. Is, then, the second of the two dates, that of the New Historian, susceptible of accurate determination? We have assumed, so far, that the terminus ad quem is given by the reference to the Persian Empire in XVI, $9 \mathrm{ff}$. If, however, it can be inferred from the use of the present tense

1) The mention of the Indian bloodhound, trained to fight with lions, in whose memory Alexander founded a city (fr. 334), as well as the reference in fr. 108 to an incident in the year $324, \mathrm{p}$ r o v e that it was not finished more than a year or so before 320 . 
in this passage that Darius had not yet been conquered by Alexander when the author wrote these words, an inference not less certain can be drawn from another passage in the papyrus, in which the border disputes between Phocis and Locris are described (XIV, 25.). The passage is as follows:

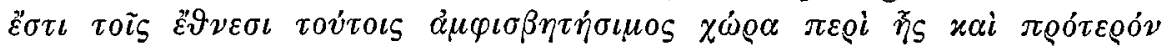

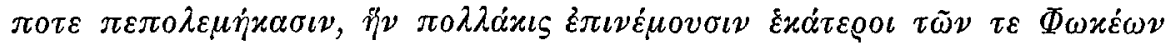

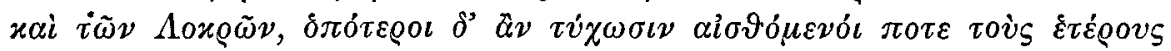

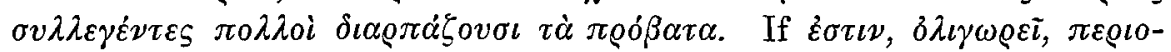

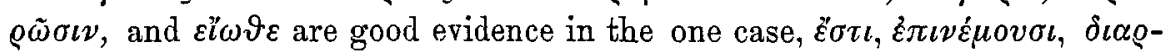
$\pi \dot{\zeta} \zeta 0 v \sigma \iota$ are good evidence in the other. To the writer these raids and retaliations are as much a part of the existing and present conditions of the Phocian Border, as cattle-driving is a part of the existing and present conditions of the County Roscommon to the leader-writer in yesterday's Times. Such conditions were no longer existing and present after 346 . After Philip's occupation of Phocis in that year, there were no longer sheep to be raided in the region of Parnassus, nor Phocians with the spirit to retaliate. Hence it can hardly be contended (and, so far as I can gather, it is not contended) that this passage can have been written after the end of the Sacred War. It follows, then, that it was written either before the outbreak of the War, i. e. before 356 , or else while it was in progress; i. e. at a moment when the Phocian question was uppermost in men's minds. It must be remembered, too, that the first stage of the War was fought out between these same Ozolian Locrians and the Phocians, hard by this same debatable territory. Is it conceivable, under these circumstances, that a writer, one of whose chief faults is discursiveness, should have refrained from a passing allusion to the War? If it is not conceivable, then the terminus ad quem stands fixed at the year 356. In 356 Theopompus was 22 years of age. The probability that he had reached the tenth book of the Hellenica before his 23rd year is one that needs no discussion. If, however, it be conceded (and I am clear that is cannot be conceded) that the passage under discussion may have been written between 356 and 4346 , it will be found, when the question of style comes to be argued, that another difficulty, in its way hardly less serious, arises when we attempt to identify the author with Theopompus.

By the objections based upon relationship, I mean those difficulties which arise out of the relations which are to be discovered between the papyrus and the other authorities for the history of this period. To take Diodorus first. If ch. 79-81 of beok XIV are compared with the papyrus, it will be seen that the points of contact are frequent and precise. It will also be seen that the order in which incidents are mentioned, and names occur, corresponds, as a rule, closely to the order of the papyrus. The correspondence is so close that the use of the New Historian by Diodorus does not admit of doubt. The only question that can be raised 
is the question whether the use was direct or indirect. Against a direct use there are two arguments that may be urged. In the first place, it is improbable that the writer of a universal history, especially when that writer is Diodorus, should have drawn his facts at first hand from a work composed on this elaborate scale. Secondly, there are errors in the dating of events, which it is difficult to account for if Diodorus was following a writer whose method is chronological, and whose dates are precise. The errors in Diodorus extend both to the chronology of the operations on land, and to that of the naval war. In narrating the campaigns in Asia Minor, he relates the appointment of Dercylidas, his arrival in Asia, the campaign in the Troad, the conclusion of an eight months' truce with Pharnabazus, and the operations in the Chersonese, under the archonship of Aristocrates, 399-8 (ch. 38). So far his dates are correct. When, however, he assigns to the same Attic year the meeting with Pharnabazus and Tissaphernes, and the conclusion of a second armistice (ch. 39), he is guilty of compressing into the space of a single year a series of events which extended over two Attic years, and possibly ran into a third. It is not until the archonship of Phormion, 396-5, (ch. 79), that he returns to the operations in Asia Minor; the intermediate years, those of Ithycles and Sunicles, 398-7 and 397-6, having been occupied exclusively with the affairs of Sicily. In the archonship of Phormion he covers the ground from the appointment of Agesilaus to the command down to the six months truce between him and Tithraustes (ch. 78, 80). The events here recorded extend, in reality, from the spring of 396 to the autumn of 395 ; i. e. they belong to three Attic years, instead of one. It is much the same with Diodorus' narrative of the naval war. Under Aristocrates (399-8) he records the appointment of Conon to the command of the fleet, and leaves him in Cilicia with a squadron of 40 vessels, ov̈ $\pi \omega$ vov $\sigma \tau \dot{v} \lambda o v$

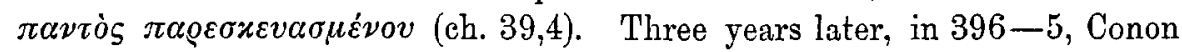
has still only 40 ships under his command at Caunus, where he is besieged by the Spartan vav́a@os, Pharax. Under the same year he narrates the revolt of Rhodes, the arrival of reinforcements from Cilicia and Phoenicia, Conon's mission to Babylon, his interview with Artaxerxes, and his return to the sea-coast. There are some difficult problems involved here, such as the date and duration of the vavaozia of Pharax. Into these questions we need not enter. It is sufficient for our purpose to point out that Conon cannot have returned before 394 , though it is possible that the command of Pharax may have been prolonged to the summer of 396 . Such chronological inaccuracies are familiar to every reader of Diodorus. We find them in his account of the interval between the Persian and Peloponnesian Wars, and of the first and the last ten years of the great War itself. One need only point to ch. 60-62 of book XI, in which the whole series of events from the siege of Eion to the battle of the 
Eurymedon are compressed into a single year. Another good example is afforded by his account of the first Sicilian Expedition (XII, 53, 54), in which, under the year of Euclides, 427-6, he relates all that happened from the embassy of the Leontines in 427 to the annexation of their territory by Syracuse in 422 . It will thus be seen that the relation between Diodorus and the author of the papyrus is precisely parallel to the relation between Diodorus and Thucydides. In both cases the only hypothesis that seems capable of explaining the facts is one which postulates an intermediary authority, whose method was non-chronological; i. e. who grouped events together according to subject, instead of following an annalistic arrangement, such as that by summers and winters which we have in Thucydides. That the authority intermediary between Diodorus and Thucydides is Ephorus has hitherto been regarded as one of the most assured results of Quellenuntersuchung. It can hardly admit of doubt that he is also the intermediary between Diodorus and the papyrus. It is true that the actual coincidences between Ephorus and the papyrus are slight (cf. XI, 10 with Eph. fr. 135, and XII, 20 with Eph. fr. 67); but Ephorus was unquestionably used by Diodorus for Book XIV, as well as for XIII and XV. (For book XIV compare 81. 4 with Eph. fr. 135; 98 with fr. $134 ; 13$ with fr. $127 ; 11$, with fr. $126 ; 22$ with fr. 129). It is far from probable that Diodorus should have followed Ephorus for the history of Alcibiades, of Lysander, of Cyrus the younger, and of Agesilaus himself in the period after the Peace of Antalcidas (cf. fr. 140 and 143), and yet should have laid him aside when he came to write of Conon and of the campaigns in Asia. It is, perhaps unnecessary to elaborate the proof of the dependence of Diodorus upon Ephorus, in view of the fact that it is conceded by E. Meyer, one of the chief supporters of the cause of Theopompus. But if the coincidences between Diodorus and the papyrus are correctly explained by the assumption that Ephorus is the connecting link between them, and if the papyrus is Theopompus, the conclusion is inevitable: Ephorus used Theopompus; or rather, Theopompus is Ephorus' sole, or principal, source for the history of this period. It is a conclusion which lands us in the grave chronological difficulties and improbabilities indicated by the editors. (see pp. 133-135). The chronological improbabilities, however, are far from constituting the most serious objection to this conclusion. The dependence of later writers upon Ephorus and Theopompus has formed the subject of a multitude of hypotheses; in fact, the discussion of the problems arising out of the relations of Plutarch and Diodorus, of Nepos and Justin, to these two great names forms a large part of the literature of Quellenforschung. Almost every conceivable hypothesis has been advanced by some one or other. The one hypothesis which had as yet occurred to no one is that of the dependence of Ephorus upon Theopompus. Next in importance, from this point of view, is the question of the relation of 
the papyrus to Xenophon. The papyrus exhibits 'a total disregard of Xenophon', to quote the editors' phrase. In place of 'total disregard' there should have been frequent contact, if the hypothesis of Theopompean authorship is correct. Porphyry (quoted by Eusebius, Praep. Evang.

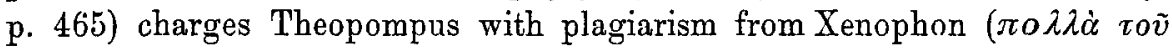

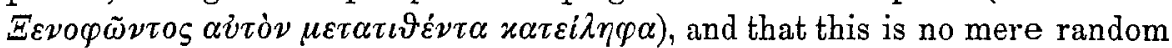
talk is proved by the fact that he adduces a particular instance, viz. the negotiations between Agesilaus and Pharnabazus (Hell. IV, 1, 29-40). Finally, let us examine the relations of the papyrus to the secondary authorities other than Diodorus, - to Plutarch and Pausanias, to Justin, Nepos, and Polyaenus. Some of these writers are regarded as dependent upon Theopompus, others as entirely independent of him; and, in some cases at any rate, there are good reasons for the view held. Clearly then, if the New Historian is rightly identified with Theopompus, we should expect to find traces of the narrative contained in the papyrus in those who are supposed to be dependent upon him, and no traces in those who are supposed to be independent of him. Precisely the reverse of this holds good. The authors which exhibit agreement with the papyrus are Pausanias, Polyaenus, and Justin; and some of the agreements are sufficiently remarkable. Polyaenus is the only ancient writer who agrees with the papyrus in associating the mission of Timocrates with Pharnabazus, instead of with Tithraustes. Justin, again, is the only ancient who mentions the mutiny of Conon's troops (cf. XVI, 29, with Justin VI, 2,11). Pausanias agrees with the papyrus (XIV, 23) in making the Locrians the Hesperian, whereas Xenophon makes them the Opuntian. But Pansanias, Polyaenus, and Justin are the writers supposed to be dependent on Ephorus and independent of Theopompus. Nepos and Plutarch, on the other hand, are the two writers whose use of Theopompus has been most generally admitted. Neither of them exhibits a single point of contact with the papyrus. Plutarch's case is the more noteworthy, as in the Agesilaus he mentions Theopompus by name as his authority no less than three times. Thus it will be seen that those who are indebted to the papyrus are not dependent on Theopompus, and those who are dependent on Theopompus are not indebted to the papyrus.

The objections on the ground of style have been kept to the last, not because I regard them as unimportant, but simply beciuse I wish to make it plain that the case against Theopompus is not based upon them. In arguing the question of style, it is not permissible, I venture to claim, to treat the extant fragments as the only evidence; and it is only if attention is confined to them, that it can be maintained that the argument for style is as much in favour of Theopompus as against him. Theopompus was ranked by antiquity 'inter auctores eloquentiae', and that by the verdict of the great uritics. Their judgment on the question of style cannot be lightly set aside. If we are to judge of the New Historian 
by what is preserved of him in the papyrus, it would be a paradox to claim for him the gift of a great style. As the editors remark, "that the historian (i. e. Theopompus) ... could have attained so high a reputation as a stylist is incredible, if his other work resembled these fragments'. There are only two ways of meeting the objection. One is to assume that the author's style cannot be judged from the fragment; the other is to assume, with Meyer and Wilamowitz, that the style of the Hellenica cannot be judged from that of the Plilippica. On behalf of the first of these positions it may be urged that the style of few authors can be fairly judged from a portion of their work selected at random. If all that we had of Thucydides was a few chapters of narrative in Book $V$, who would have divined his style? To this it may be replied that, though a style cannot always be inferred from a few chapters, an incapacity for style can be. A dozen chapters of Diodorus would suffice as well as all the extant books to reveal his nakedness. It would be unfair to our author to rank him with Diodorus as a stylist. But is it unfair to assert that the note of his literary style is dulness? Or am I peculiar in finding that his periods leave upon my mind an impression of insufferable monotony? The uniform structure of the sentences, and the poverty in particles, is especially worthy of note. While $\mu \dot{\varepsilon} \nu$ ox $\nu$ recurs with wearisome iteration, $\ddot{\omega} \sigma \tau \varepsilon$ is found only twice in something like 500 lines. Some curious statistics relating to the use of particles and conjunctions will be found in an article by K. Fuhr, in the Berliner Philologische Wochenschrift for Feb. 15 of the present year. The bitterness which Cicero singles out in 'Theopompus, the fire and passion which glow even in the fragments, the 'elatio atque altitudlo orationis suac', are all alike incredible of our historian. It is not 'the bit' assuredly that he needs. There are few who have needed so much 'the spur.' If I interpret the second argument rightly, it would come to this. The Hellenica was the work of Theopompus' youth, written before his thirtieth year. For a work treating of so wide a range of subjects, the mere collection of information, together with the sifting and arrangement of materials (and Dionysius gives Theopompus praise for his careful and diligent preparation), would absorb the energies of a young and inexperienced writer. Busy in amassing information, he had no time left for acquiring the graces of literary composition. Possibly (for this has been suggested), he had not yet gone to school with Isocrates when the Hellenica was given to the world. Need we be surprised then, if this, the product of his youth, should stand in marked contrast, in point of style, to the Philippica, the fruit of his mature genius? Here at least, in dealing with this plea, we can appeal to something more solid than a subjective impression. We can produce the most satisfactory of witnesses, a date. Of all the facts alleged about Theopompus, the best attested is his victory over his master Isocrates, in the competition instituted by Arte- 
misia in honour of Mausolus. The story is told by Aulus Gellius $(X, 18)$, by Plutarch (Vitae $X, O r$. p. $383 \mathrm{~B}$ ), and by Suidas. It rests, however, upon a better authority than theirs'. It rests upon the authority of Theo-

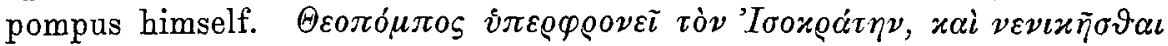

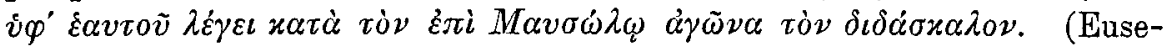
bius, Praep. Evang. X, 3 p. 464 C). Mausolus died in 352, Artemisia in 350 , and the vear was an Olympie one, according to Suidas. It stands fixed therefore for 352. Thus in 350, or any later year before 346, Theopompus was already the master of that style which gave to his I'hilippica its

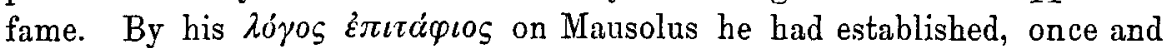
for all, his title to be classed among the great stylists of the world. The time, that (according to the hypothesis under discussion) should have been spent in amassing materials, has been devoted to perfecting the gifts of style. The pupil has already worsted his master with weapons borrowed from that master's armoury. To put it shortly. If the composition of the unknown author's work is assigned to a date earlier than 356 , the chronological argument is fatal to his identification with Theopompus. If the composition is assigned to a later date, the argument from style is not less fatal.

To the three objections which I have attempted to establish, the argument from date, the argument based upon the agreements and disagreements with other writers, and the argument from style, it will probably be replied somewhat as follows. We admit the force of these objections. Taken singly, they are strong: their cumulative force is undeniably strong. But what is the alternative to Theopompus? A mere phantom form. If we must elect between the two, we prefer the flesh and blood of the one to the shadowy, unsubstantial form of the other. The one great, initial improbability of the one hypothesis constitutes a greater difficulty than the combined improbabilities attendant on the other.

That Cratippus is, in a sense, unsubstantial, is true. That is to say, there is very little of him. The fragments add up to little more than a dozen lines. That there is anything shildowy about lis personality, I must respectfully deny. $\mathrm{He}$ is referred to by three of the ancients, and by three only; namely by Dionysius of Halicarnassus, by Plutarch, and by Marcellinus. The reference in the last of these writers ${ }^{1}$ ) is enigmatical, and I have no conjecture to offer. There are two references in Plutarch, and one in Dionysius. From Dionysius ${ }^{2}$ ) it may be gathered that he was,

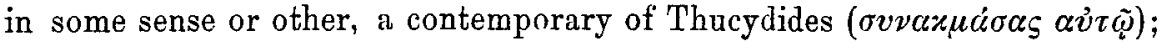
that his object was to complete, in some sense or other, the work of

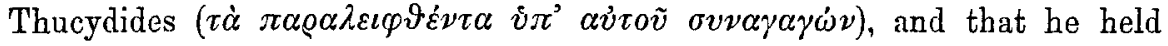
the view that speeches were out of place in a serious history. One of the passages in Plutarch ${ }^{3}$ ) tells us little more than that he had treated in his history of the mutilation of the Hermae. From the other passage,

1) Vita Thucyd. \$ 46. - 2) De Thucyd. 16. - 3) Vit. Orat. II, 1, p. 834. 
however, it is possible to infer his nationality and his date, as well as the scope of his work ${ }^{1}$ ). He was an Athenian, of the Great Age, and his narrative extended from 411 or 410 to the battle of Cnidus. That he was an Athenian is clear for two reasons. Firstly, all the other names in Plutarch's list - Thucydides, Xenophon, Clitodemus, Diyllus, Philochorus, Phylarchus - are Athenian; and secondly, that he should be an Athenian is required by the argument. The point of the passage is the antithesis between the makers of history and the writers of it. The makers of history enumerated by him are, without exception, Athenian worthies -

- Pericles, Phormio, Nicias, Demosthenes, Cleon, Myronides, Tolmides, Alcibiades, Theramenes, Thrasvbulus, Thrasyllus, and Conon. It follows that the writers must similarly be Athenian. It is history, as made by Athenians, that he is contrasting with history, as written by Athenians. As a matter of fact, it is not only a list of Athenian historians, but it is very nearly a complete list. Androtion is the one noteworthy name that is missing. That he belongs to the same age as Thucydides and Xenophon, is also clear; for, as Clinton saw long ago, the order of the names in the list is chronological. The first in the list is Thucydides, who is admittedly the earliest; the last is Phylarchus, who is admittedly the latest. After Xenophon comes Clitodemus, the first of the Atthidographs; intermediate between him and Phylarchus are Diyllus and Philochorus, both of whom run over into the third century. And the period covered by his narrative is sufficiently determined by the exploits adduced. The list be-

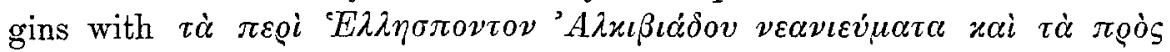

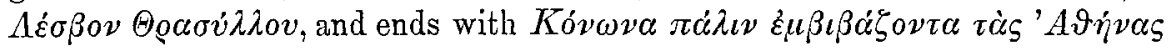
sis $\tau \dot{\eta} \nu \vartheta \alpha \dot{\lambda} \alpha \tau \tau \alpha \nu$. It looks as if his work started at some point in the eighth book of Thucydides. In that case, the mutilation of the Hermae must have been touched upon in connexion with the recall of Alcibiades. It is fairly certain that it did not extend beyond the battle of Cnidus. Had it reached to the Peace of Antalcidas, Plutarch could not have failed to include a reference to the achievements of 'Thrasybulus in 390-89.

Such then being the data with regard to Cratippus, how far are they in harmony with the indications afforded by the papyrus itself? It hardly needs to be pointed out that the indications as to the period are as favourable to Cratippus as to Theopompus. As against the former, they afford no sort of presumption in favour of Theopompus. As to the writer's nationality, it is conceded that the internal evidence is not against his being an Athenian. I should be inclined to go further, and to claim that it decidedly supports the hypothesis of an Athenian origin ${ }^{2}$ ). $\mathrm{He}$

1) De glor. Athen. I, p. 345 E.

2) I am glad to find myself in complete agreement with de Sanctis on this point. He brings some additional arguments, e. g., the detailed account of the trivial incident of Demaenetus and the trireme. 
seems to view the politics of Boeotia and Phocis from the point of view of an outsider. His attitude towards Athenian politics is one of much less detachment. If there is anything in the view that the general tendency of his narrative is to exalt Conon at the expense of Agesilaus, that too would afford a further corroboration. There remains the question of date. There is a passage towards the end of column XIII which perhaps affords a clue. The writer is constrasting the ruin caused by the occupation of Decelea with the effects of the annual invasions in the earlier part of the Peloponnesian War. There are touches in the description of the horrors of the Decelian War which seem to me

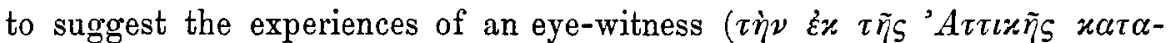

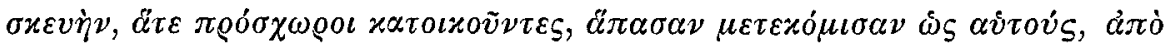

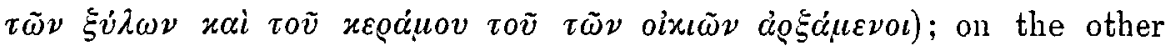
hand, neither an eye-witness nor a contemporary could have made so light

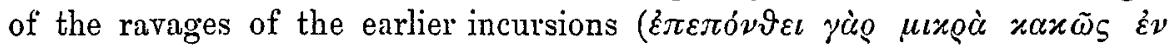

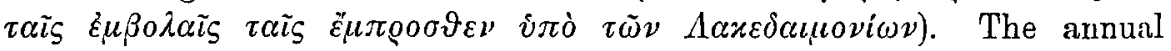
invasions ceased in 425 . If the writer is an Athenian. he cannot have been born earlier than 430 ; and if the inference is correct that he was a contemporary of the Decelean War, he cannot have been born much later than 425. The terminus ad quem is 356. The general tone of the references to Boeotian affairs seems to exclude a date immediately after the Peace of Antilcidas. The lapse of at least a dozen years seems to be required. Any date, however, between 375 and 356 would satisfy the conditions. How far can such a date be mide to fit Cratippus? A work which was designed to complete what Thucydides had left unfinished cannot have been contemplated, ex hypothesi, until after Thucydides' death. It is a fair inference froin the passage in the de gloria Atheniensizm that it was a considerable work. There is nothing, therefore, to occasion difficulty in the assumption that it was not completed till twenty years after the battle of Cnidus. Nor is there any real difficulty in the phrase used by Dionysius to indi-

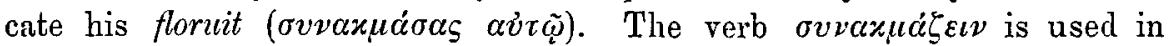
even a looser sense than the term 'contemporary' is with us. 'The references make it clear that it could be applied to any case in which two persons entered jointly into a series of events. Aristotle (ap. Plut. Lycur. I)

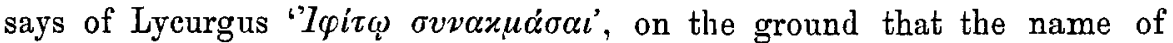
the former was inscribed on the Olympian quoit. But we need not go further afield than Theopompus himself (fr. 26). Once more it is Photius who is our authority. ' $\Sigma v \nu \alpha x \mu \alpha \dot{\sigma} \sigma \alpha \iota d \dot{\varepsilon} \alpha \dot{v} \tau \dot{s} \varsigma \dot{\varepsilon} \alpha v \tau \dot{\partial} \nu \lambda \dot{\varepsilon} \gamma \varepsilon \iota$ (Theopompus)

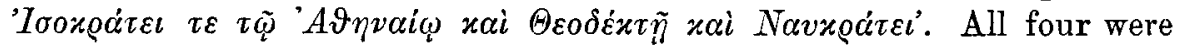

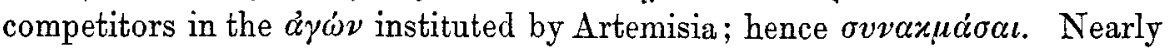
sixty years separate the date of Isocrates' birth from that of Theopompus. If Cratippus was born about 425, he was, in all probability, not much more than forty years the junior of Thucydides. If $\sigma v v \alpha \varkappa \mu \alpha \sigma^{\sigma} \alpha \iota$ is consistent 
with a difference of sixty years in the one case, it is not inconsistent with a difference of forty years in the other. A further difficulty with regard to the question of date has been found in the avoidance of hiatus, which is a marked feature in the style of the fragment. Fuhr goes so far as to regard this difficulty as of itself decisive against Cratippus. I cannot attach so much importance to this objection. The Panegyricus of Isocrates was published in 380 . The avoidance of hiatus is observed in it as strictly as it is in the papyrus. It was the fashion, and in 370 it was the latest fashion. It was a trick of style; a process, largely mechanical, which had the advantage of being easily acquired. To a writer with no native gift of style, so artificial a grace would have peculiar attractions. It is much the same now-a-days with punctuation. The duller the style, the more scrupulously accurate is the use of comma and colon.

It remains to apply to Cratippus the tests which we have applied to Theopompus. So far as the scope of the work is concerned, they stand on a level. They both wrote a continuation of Thucydides, and both came down to the battle of Cnidus. This is the strongest of arguments as against all other competitors; it is clearly not an argument which can decide between these two. The argument from date affords no insuperable objection against Cratippus. Upon grounds of style there are, at any rate, strong prima facie reasons for deciding against Theopompus. As the editors admit, "the identification of $\mathrm{P}$ with Theopompus necessitates a radical alteration in the ordinary conception of his style'. Of the style of Cratippus we know little, but that little is significant. A writer who held that speeches served only to obstruct the narrative, and who apparently imagined that Thucydides had himself come to the same conclusion in regard to the speeches in his own history, must have been wholly free from the taint of rhetoric. He is likely too, to have suffered from the defects of his quality. If we are to imagine a style for him, it would be one not dissimilar from the style of our fragment. We must not make too much of the absence of speeches in the papyrus. It may be the result of accident. We may, however, fairly contend that the New Historian would have been well advișed in avoiding speeches. The test of relationship cannot, from the nature of the case, be applied to Cratippus, in the sense, and in the degree, that it has been applied to Theopompus. Still, the coincidences between Diodorus and the fragment are all in favour of Cratippus. Ephorus must have had an authority whom he could follow for this period of the history, and it was clearly a well-informed authority. If that authority was not, solely or principally, Xenophon, there is no other writer so likely as Cratippus. Further, there is the total disregard of Xenophon. This needs no explanation, if the author is Cratippus, and if he wrote before 360 .

Finally, we are still confronted by the objection that, if the author 
of a work so important and so lengthy is to be identified with Cratippus, it is inconceivable that the latter should have left so few traces upon the literature of antiquity. To this objection there are three answers. In the first place, Cratippus, whether he is identified with the New Historian or not, was in any case a considerable author. Plutarch sets him midway between the two great classics, and ranks him above writers of whom the traces are frequent enough. Secondly, Plutarch and Dionysins had read him, and Plutarch assumes that he was known to the reading public. Thirdly, there were special reasons why Cratippus should not be quoted. He was not likely to be quoted for style, or for the use of rare words. Unlike the Atthidographs, he did not appeal to antiquarian interests. What is most important of all is that he was used by Ephorus. The excollent materials which he furnished were served up by Ephorus in a literary form more agreeable to the tastes of that generation. All that anybody wonld care to learn, could be learnt more conveniently from the latter writer. And if there were any who wished for a fuller treatment of that period of history, they were likely to go to Xenophon or Theopompus, rather than to a writer who was probably more accurate, but certainly more dull. And after all, if Theopompus were only the anthor of the Hellenica, how little we should have of him. In Müller's edition there are some twenty fragments, but of these twenty, eight are simply names of places quoted from the Hellenica by Stephanus of Byzantium. To take a parellel case. For the forty years that followed the death of Alexander the principal source of the later writers was Hieronymus of Cardia. For much of this period he was possibly the sole primary authority. We know more about him than we do about Cratippus, for the reason that he played a part in the politics of the age. But in spite of his importance, there remain but fourteen fragments; and these would have been reduced to six, if his work had not chanced to afford to Lucian some welcome examples of longevity, and if he had not been the principal authority for a life of peculiar interest to the Roman world, the romantic career of Pyrrhus.

It is with some degree of hesitation that I have ventured to put forward a view of the authoriship of the famous fragment which is diametrically opposed to the identification faroured by Wilamowitz, by Meyer, and by the editors themselves. No serious student of antiquity can affect to disregard the weight of their combined authority. There is Wilamowitz - in the field of Greek scholarship, $\mu \dot{\varepsilon} \gamma \iota \sigma \tau o \varsigma \delta \mu o \lambda o \gamma \circ v \mu \varepsilon \dot{\varepsilon} \nu \omega \varsigma \varkappa \alpha i \tau \tilde{\omega} \nu$

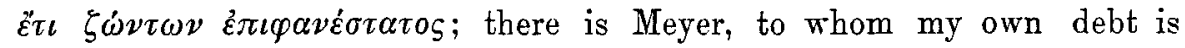
greater than to any other historian of Greece since the days of Grote; and lastly, there are the editors. In spite of this weight of authority, I cannot but express the conviction that the identification of the writer with Theopompus is an untenable hypothesis. And if he is not Theo- 
pompus, it is somewhat perverse to deny that he is Cratippus. The truth is, that it is not in politics only that it takes time to get accustomed to a new idea; and two years ago Cratippus was a new idea. It was only natural that scholars should shrink from attributing a work so considerable to an author with whom erudition itself had barely a bowing acquaintance. I trust that I have succeeded in showing that he is, in reality, a respectable writer, whom no one need be ashamed to acknowledge.

While the above was passing through the press, two other articles dealing with the identity of $\mathrm{P}$ have appeared. In the April number of the English Historical Review there is a paper by Professor Goligher, of Trinity College, Dublin, on The New Greek Historical Fragment. The conclusions, positive and negative, at which the writer arrives agree with those which I have endeavoured to establish. Upon one point, however, I must differ from him. He maintains, against the editors, that Plutarch (in Ages. 10) follows P against Xenophon. On the contrary, Plutarch in the Agesilaus exhibits the closest contact with Xenophon, for the campaign of 396 as well as for the year 395 , and as the editors quite correctly state, 'shows no trace of connection with P.' The presence of Tissaphernes at the battle is obviously a mere slip on Plutarch's part; a very pardonable slip, if it were not for the words at the beginning of Hell. III, 4, 25. With Busolt's article in Hermes, 43, 2 it is clearly impossible to deal within the compass of a note. The article is, in any case, an exceedingly important contribution to the criticism of the New Historian. It appears to me. however, to be very far from establishing his identity with Theopompus. The coincidences of expression between $\mathrm{P}$ and Xenophon are singularly slight and unconvincing. The absence of any more evident ones constitutes a strong argument against the use of the Hellenica by $\mathrm{P}$. If Busolt's view of the relation of $\mathrm{P}$ to Xenophon is correct, it is remarkable that so much space should be devoted to subjects (e. g. the naval warfare) left untouched by the latter. If his view of the historical methods of Theopompus is also correct, it will follow that much that has been ascribed to the inventive powers of Ephorus is really due to the imagination of Theopompus (e. g. the account of Arginusae). In other words, Ephorus becomes a pale reflection of Theopompus. I find it hard to believe that, within a dozen years of the appearance of Xenophon's Hellenica, Theopompus should have published a history, which.was in the main a conceited and ignorant perversion of Xenophon's rarrative, and that, within a dozen years of the publication of Theopompus' work, Ephorus should have made it the basis of his history, for the period with which it dealt. If such were the relations of Ephorus to Theopompus, it is strange that no ancient writer should have hinted at the dependence of the former of these writers upon the latter. 